\title{
Grammar Tests as a Motivational Tool for Grade 7 Students of Assumption College Thonburi (ACT)
}

\author{
APINYA BOONMUSIK \\ Assumption College, Thonburi, Thailand
}

\begin{abstract}
Bio Data:
Apinya Boonmusik obtained her Bachelor of Education from Phranakhon Rajabhat University, and is currently taking courses in the Teaching English as an International Language (TEIL) Program, Faculty of Education, Shinawatra University. Her experience for teaching is over 20 years. She has been an instructor at Assumption College Thonburi from the year 2001 up to present.
\end{abstract}

\begin{abstract}
This study focused on the use of teacher-designed Grammar tests for assessing Student s' grammar knowledge on certain topics after the same classroom learning experience. Traditional grammar tests are used with sample students to assess them along with two teacherdesigned tests. Test 1 is made up of multiple choice, arranging words into sentence, gap-fills, and competing the text of the sentence. Test 2 on the other hand is made up of the same test types but provided with colorful pictures, chart presentations, and simplified choices, it was found that students were more motivated in trying their best to answer all questions in test 1 and test 2 .
\end{abstract}

\section{Introduction}

Learning grammar is somewhat difficult for many students. On the other hand, teaching grammar is a challenge to language teachers who have students who do not want to learn grammar. Therefore, teachers are challenged to make their grammar test as a motivational tool in learning English subject.

Using the right kind of grammar question at the right time can be enormously important in giving us a clear understanding of our students' abilities, but teachers must also be aware of the limitations of each of these task or question types so that 
we use each one appropriately. Also be aware that the standard measure of assessment, which covers the content and purpose of the measure the same general purpose of the test. Just fine, but the contractor retained to test it as an inspiration to the recipient to test the positive attitudes that will affect the learning of English grammar.

Some of these test types are: Multiple Choice, Transformation, Gap-filling, Cloze, and Error correction. In a Multiple question type there is a stem and various options to choose from. The advantages of this question type are that it is easy to mark and minimizes guess work by having multiple distracters. Multiple choice can be used to test most things such as grammar, vocabulary, reading, and listening. The student has to paraphrase the whole meaning of the sentence in the Transformation type.

\section{Review of Related Literature}

In a study conducted by W.W. Charters entitled Constructing a Language and Grammar Scale, (1992) "in the correction of language forms upon the language of levels without knowledge of grammatical rules and definitions, it was found that few teachers had definite information about the errors which their children made" (p.249). This means that grammatical rules greatly affect the form of language. Teachers therefore should emphasize towards their students the importance of grammatical rules and definitions in order for the children to use the language correctly both in speaking and in writing.

Although many of contemporary teachers use the alternative method in teaching grammar like communicative method, they still continue to integrate 
grammar instructions into its traditional approach. For example, RichardsGallo, and Renandya (2001) discovered that many of the respondents to their survey, although suggesting they prepared materials and activities to teach English language in a communicative way (deemphasize grammar instruction), they nevertheless reported that they still believe grammar is central to language learning and that "direct grammar teaching would result in more accurate language use" (p. 55). In this study, it was pointed out that teachers can use multiple approaches in teaching grammar. Although the common trend at the present time is the communicative approach, the advantages of using grammar translation method and direct method can't be denied. Thus, translating the grammar rules into student's first language and discussing grammar structures to second language has also helped the students use English language communicatively.

In a classic research studies into grammar and other writing mechanics errors conducted by Maxine Hairston in 1981, she discovered the kind of errors in writing and speaking professional people regarded as most serious. "Hairston's respondents were most upset by a class of errors she called status marking errors. Such errors may not prevent writers and speakers from being understood, but they mark people who use them as poorly educated, low income, and low social status." Her research is significant because the professional's wrong use of grammar may result in poor employment opportunities. This will hinder them to express their thoughts coherently during interviews and employment examination. 


\section{Background of Study}

Assumption Colllege Thonburi (ACT) school is a private school located in Bangkae, Bangkok. It was established by the St. Gabriel Foundation in Bangkok. At present, ACT caters quality education from primary to senior high school with a population of mainly Thai students. In pursuit of global competitiveness, the school offers three educational programs: Inventive English Program or IEP, English Program or EP and The Best in English Language Learning or BELL Program.

Students who want to enroll in ACT need to take an entrance examination, specifically the incoming grade 1, 7, and 11 students. For ACT grade 6 students who plan to continue their junior studies will no longer take the test and will automatically be enrolled. Same rules apply to ACT grade 7 students who wish to continue their senior studies.

A part of assessing the student's performance is evaluating their grammar knowledge. The researcher would like to evaluate whether the grammar test becomes a motivational tool in learning English or not for newly accepted Grade 7 students.

Grammar Test 1 and Grammar Test 2 on topics such as subject-verb agreement, adverb of frequency, present simple tense, and positive, negative and interrogative sentences were given to randomly selected 50 grade 7 students. Test 1 is made up of multiple choice, arranging words into sentence, gap- fills, and completing the text of the sentence. Test 2 on the other hand is made up of the same test types but provided with colorful pictures, chart presentations, and simplified choices. 


\section{Statistical Treatment}

\section{Presentation 1}

A table comparing the percentage of passing and failing rate of Present Simple Test 1

\begin{tabular}{|l|c|c|c|c|}
\hline Subject & $\begin{array}{l}\text { No. of } \\
\text { Students } \\
\text { who passed } \\
\text { the test }\end{array}$ & $\begin{array}{l}\text { Percentage } \\
\%\end{array}$ & $\begin{array}{l}\text { No. of } \\
\text { Students who } \\
\text { failed the test }\end{array}$ & $\begin{array}{l}\text { Percentage } \\
\%\end{array}$ \\
\hline $\begin{array}{l}\text { Agreement } \\
\text { of subject } \\
\text { and verb }\end{array}$ & 25 & $50 \%$ & 25 & $50 \%$ \\
\hline $\begin{array}{l}\text { Adverb of } \\
\text { frequency } \\
\text { usage }\end{array}$ & 31 & $62 \%$ & 19 & $38 \%$ \\
\hline $\begin{array}{l}\text { Negative } \\
\text { and } \\
\text { Question } \\
\text { form }\end{array}$ & 41 & $82 \%$ & 9 & $18 \%$ \\
\hline $\begin{array}{l}\text { Communicat } \\
\text { ion }\end{array}$ & 16 & $32 \%$ & 34 & $68 \%$ \\
\hline
\end{tabular}




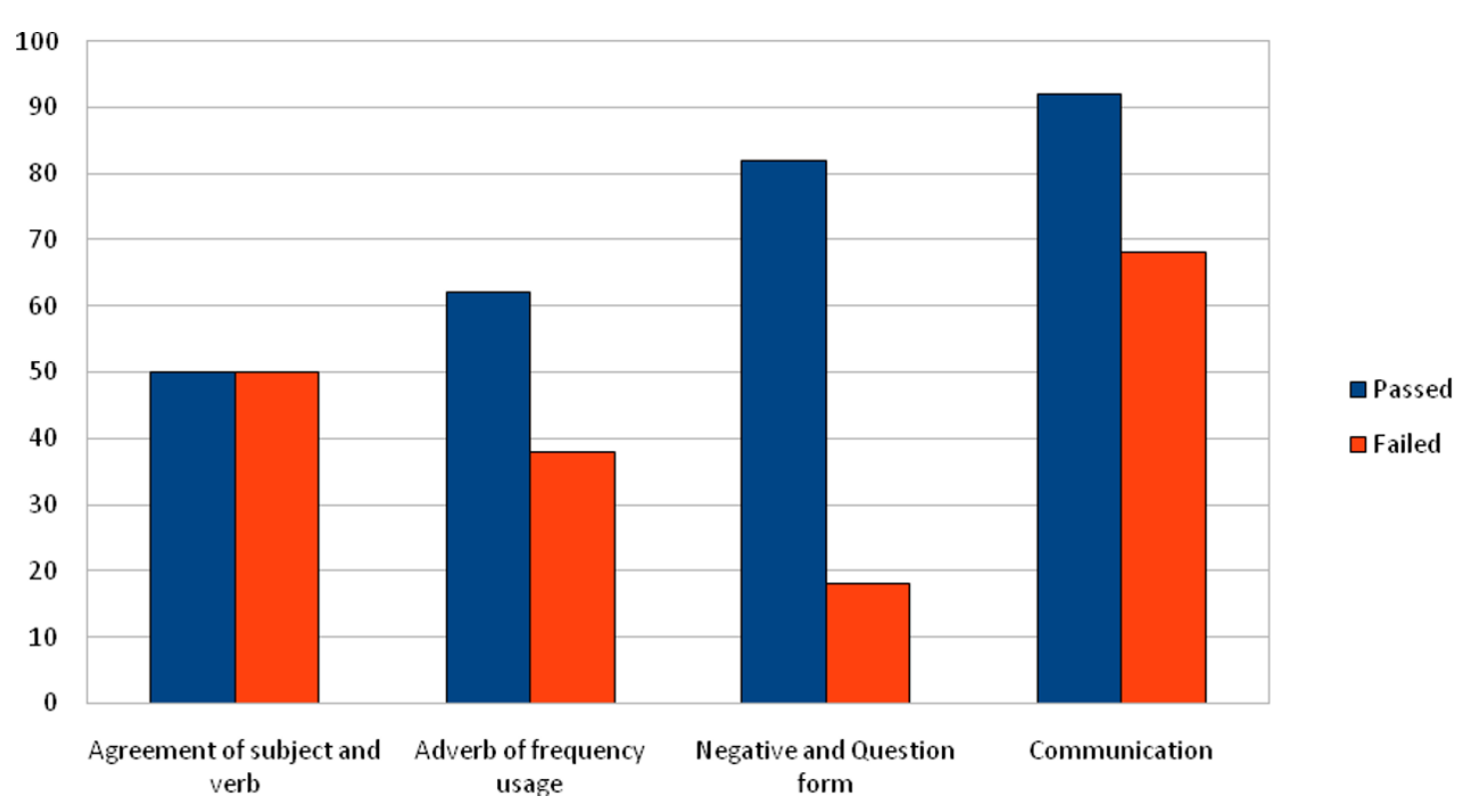

A graph comparing the percentage of passing and failing rate of Present Simple Test 1

The table and graph in presentation 1 shows that half of the respondents passed on the subject-verb agreement while the other $50 \%$ failed. Students got a higher passing rate to the rest of the test, $62 \%$ from the Adverb of the frequency usage $82 \%$ negative and question form and $32 \%$ from communication test. Percentage on the failing rate how ever in is relatively high, 38\% in Adverb of the frequency usage, $18 \%$ in negative and question form and $68 \%$ in communication test.

\section{Presentation 2}

A table comparing the percentage of passing and failing rate of Present Simple Test 2

\begin{tabular}{|l|l|l|l|l|}
\hline Subject & $\begin{array}{l}\text { No. of } \\
\text { Students } \\
\text { who passed } \\
\text { the test }\end{array}$ & $\begin{array}{l}\text { Percentage } \\
\%\end{array}$ & $\begin{array}{l}\text { No. of } \\
\text { Students } \\
\text { who failed } \\
\text { the test }\end{array}$ & $\begin{array}{l}\text { Percentage } \\
\%\end{array}$ \\
\hline
\end{tabular}




\begin{tabular}{|l|c|c|c|c|}
\hline $\begin{array}{l}\text { Agreement of } \\
\text { subject and verb }\end{array}$ & 46 & $92 \%$ & 4 & $8 \%$ \\
\hline $\begin{array}{l}\text { Adverb of } \\
\text { frequency usage }\end{array}$ & 48 & $96 \%$ & 2 & $4 \%$ \\
\hline $\begin{array}{l}\text { Negative and } \\
\text { Question form }\end{array}$ & 38 & $76 \%$ & 12 & $24 \%$ \\
\hline Communication & 46 & $92 \%$ & 4 & $8 \%$ \\
\hline
\end{tabular}

A graph comparing the percentage of passing and failing rate of Present Simple Test 2

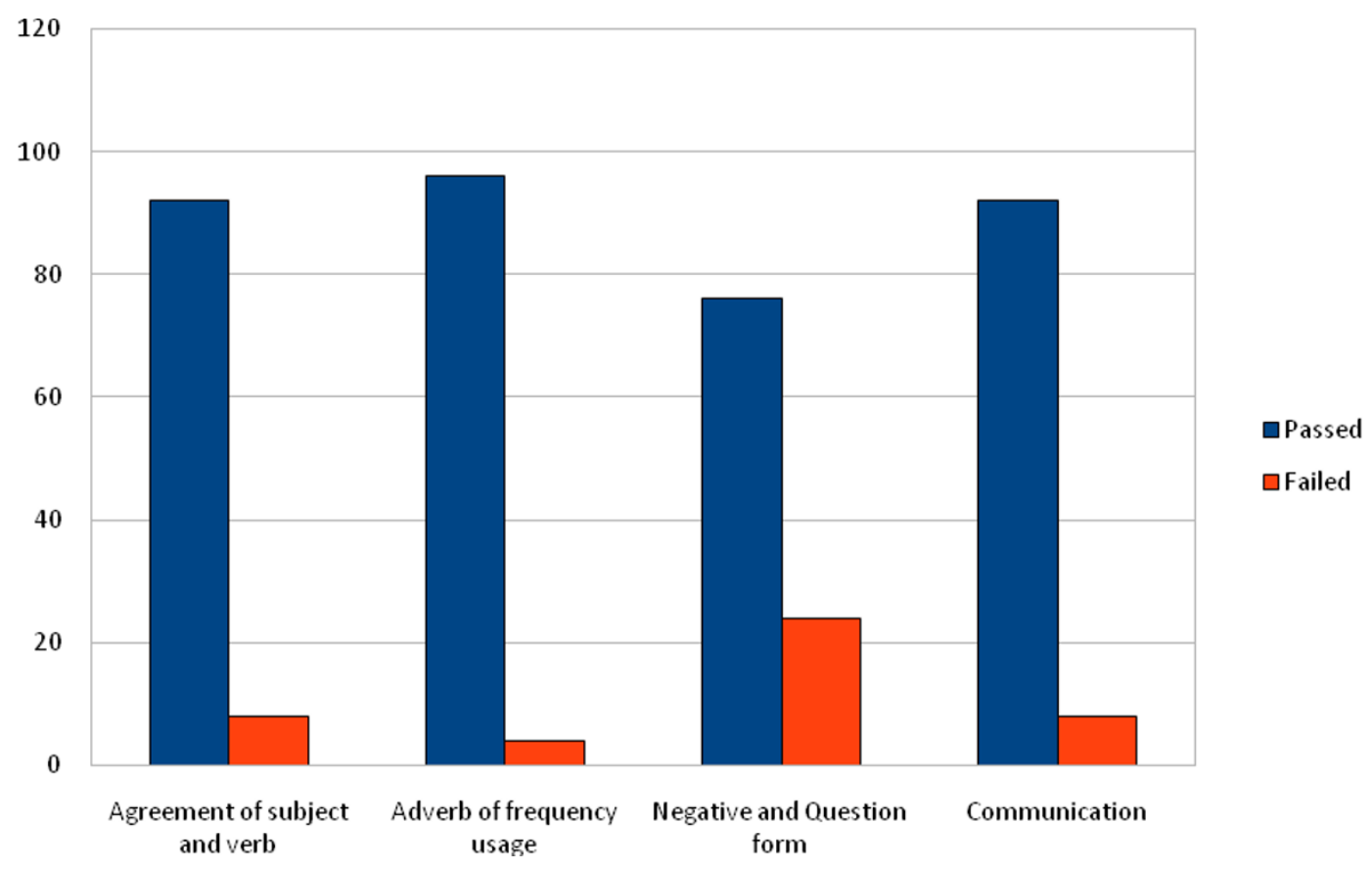

The table and graph in presentation 2 shows a great improvement on the four kinds of test Adverb of frequency usage got the highs passing rate and the lowest failing rate, $96 \%$ and $4 \%$ respectively. Subject verb agreement and communication got the same passing and failing rate, both $96 \%$ and $8 \%$ respectively. Negative and Question form however, got the lowest passing rate and the highest failing rate, $76 \%$ and $24 \%$ respectively. 


\section{Presentation 3}

A table compar0ing the percentage of Present Simple Test 1 and 2

\begin{tabular}{|l|c|c|c|c|}
\hline Subject & $\begin{array}{l}\text { Total score } \\
\text { of students } \\
\text { for test 1 }\end{array}$ & $\begin{array}{l}\text { Scoring } \\
\text { average as a } \\
\text { percentage. } \\
\%\end{array}$ & $\begin{array}{l}\text { Total score } \\
\text { of students } \\
\text { for test 2 }\end{array}$ & $\begin{array}{l}\text { Scoring } \\
\text { average as a } \\
\text { percentage. \% }\end{array}$ \\
\hline $\begin{array}{l}\text { Agreement of } \\
\text { subject and verb }\end{array}$ & 236 & $47.2 \%$ & 377.5 & $75.5 \%$ \\
\hline $\begin{array}{l}\text { Adverb of } \\
\text { frequency usage }\end{array}$ & 257 & $51.4 \%$ & 414 & $82.8 \%$ \\
\hline $\begin{array}{l}\text { Negative and } \\
\text { Question form }\end{array}$ & 302 & $60.4 \%$ & 372.5 & $74.5 \%$ \\
\hline Communication & 157 & $31.4 \%$ & 380 & $76.0 \%$ \\
\hline
\end{tabular}

A graph comparing the difference of Present Simple Tense between test 1 and test 2

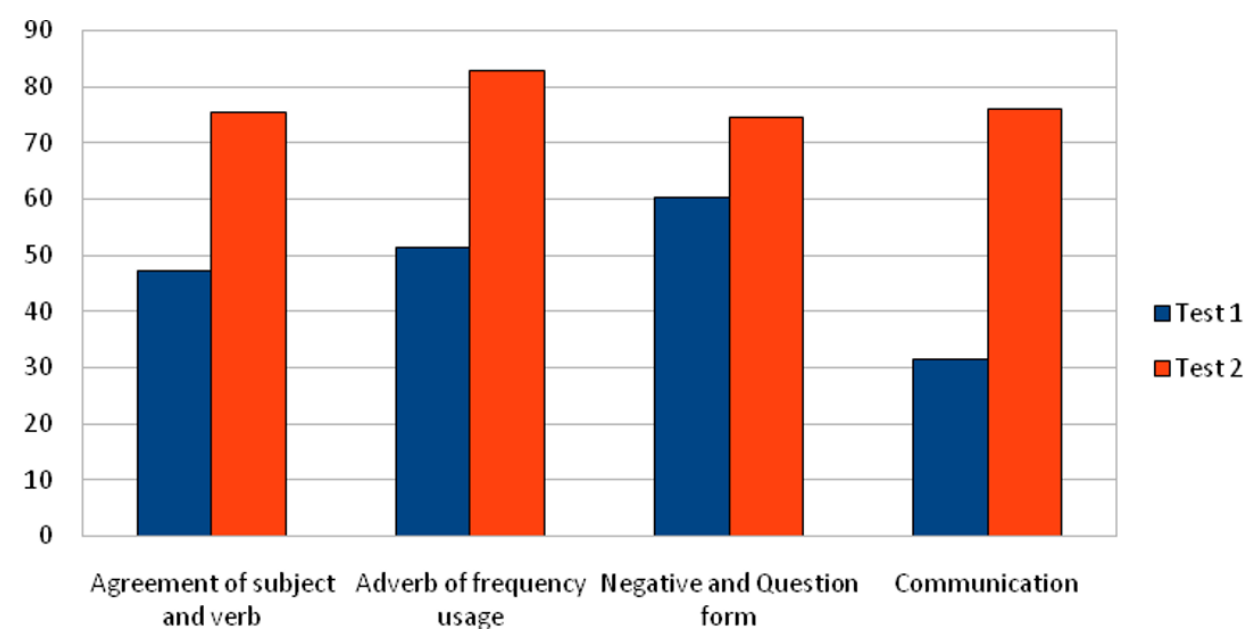

The table and graph in presentation 3 shows the comparison of the result of test 1 and test 2 . Test 2 shows a higher passing rate than test 1 . Adverb of frequency usage in test 2 got the highest percentage of $82.8 \%$, while $51.4 \%$ in test 1 . 
Communication test in test 2 got $76 \%$ and $31.4 \%$ in test 1 . Agreement of subject and verb in test 2 is $82.8 \%$ and $51.4 \%$ in test 1, 74.5\% from the Negative and Question form in test 2 and $60.4 \%$ in test 1.

\section{Presentation 4}

A table showing the rate of evaluation from the students in Test 1

\begin{tabular}{|c|c|c|c|c|c|c|c|c|}
\hline \multirow{2}{*}{$\begin{array}{c}\text { Criteria of } \\
\text { Evaluation }\end{array}$} & \multicolumn{2}{|c|}{ Rating 4 } & \multicolumn{2}{c|}{ Rating 3 } & \multicolumn{2}{c|}{ Rating 2 } & \multicolumn{2}{c|}{ Rating l } \\
\cline { 2 - 9 } & $\begin{array}{c}\text { No. of } \\
\text { Students }\end{array}$ & $\begin{array}{c}\text { Percentage } \\
\%\end{array}$ & $\begin{array}{c}\text { No. of } \\
\text { Students }\end{array}$ & $\begin{array}{c}\text { Percentage } \\
\%\end{array}$ & $\begin{array}{c}\text { No. of } \\
\text { Students }\end{array}$ & $\begin{array}{c}\text { Percentage } \\
\%\end{array}$ & $\begin{array}{c}\text { No. of } \\
\text { Students }\end{array}$ & $\begin{array}{c}\text { Percentage } \\
\%\end{array}$ \\
\hline $\begin{array}{c}\text { Level of } \\
\text { learning } \\
\text { objective }\end{array}$ & 9 & $18 \%$ & 23 & $46 \%$ & 18 & $36 \%$ & - & $0 \%$ \\
\hline $\begin{array}{c}\text { Content } \\
\text { coverage }\end{array}$ & 19 & $36 \%$ & 25 & $50 \%$ & 5 & $10 \%$ & 1 & $2 \%$ \\
\hline $\begin{array}{c}\text { Practice of } \\
\text { writing } \\
\text { skills }\end{array}$ & 14 & $28 \%$ & 24 & $48 \%$ & 21 & $42 \%$ & 1 & $2 \%$ \\
\hline $\begin{array}{c}\text { Length of } \\
\text { exam (time } \\
\text { to } \\
\text { complete) }\end{array}$ & 17 & $34 \%$ & 20 & $40 \%$ & 8 & $16 \%$ & 5 & $10 \%$ \\
\hline $\begin{array}{c}\text { Exam } \\
\text { constructio } \\
\text { n }\end{array}$ & 10 & $20 \%$ & 18 & $36 \%$ & 17 & $34 \%$ & 5 & $10 \%$ \\
\hline $\begin{array}{c}\text { Test re- } \\
\text { usability }\end{array}$ & 11 & $22 \%$ & 22 & $44 \%$ & 14 & $28 \%$ & 3 & $6 \%$ \\
\hline $\begin{array}{c}\text { Prevention } \\
\text { of cheating }\end{array}$ & 10 & $20 \%$ & 12 & $24 \%$ & 6 & $12 \%$ & 2 & $4 \%$ \\
\hline
\end{tabular}


A graph showing the rate of evaluation from the students in Test 1

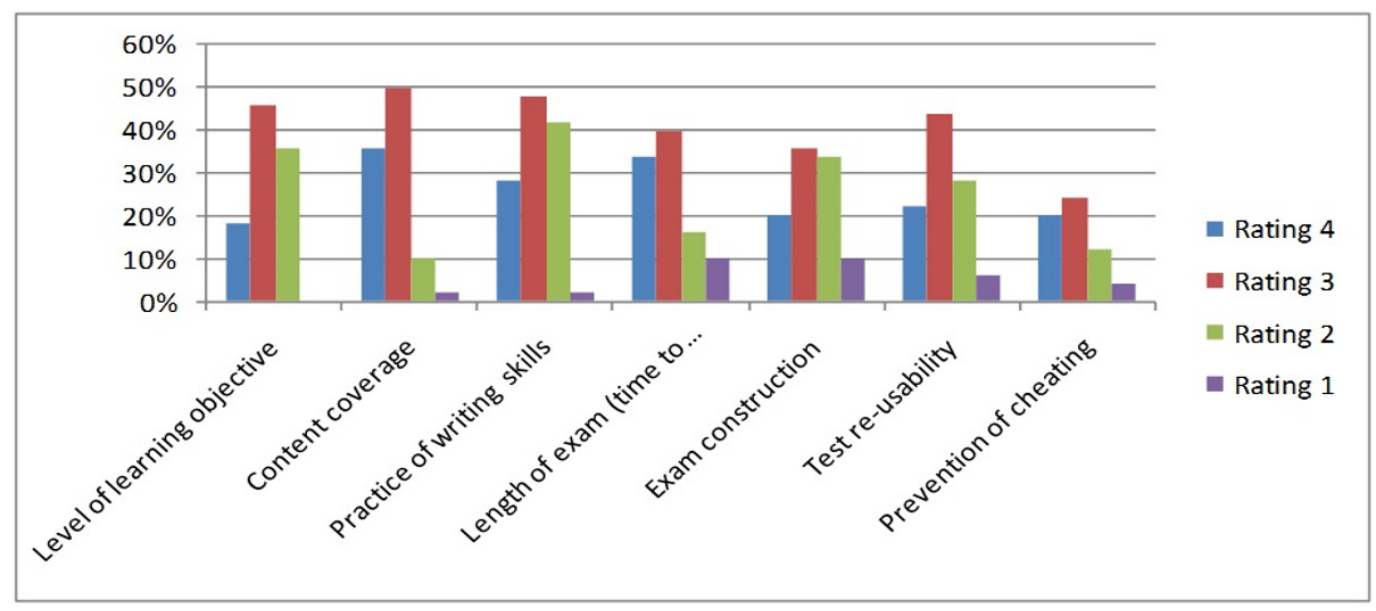

The graph and table in presentation 4 shows the ratings from the students for Test 1, 4 being the highest and 1 as the lowest. For the rate of 4 , Content Coverage got the highest favor from the survey (36\%), followed by Length of Exam and Practice of Writing skills (34\% and $28 \%$ respectively). Test reusability on the other hand is 22\% while Exam Construction and Prevention of Cheating got the same percentage which is $20 \%$. Level of Learning Objective got the lowest percentage which is $18 \%$. 


\section{Presentation 5}

A table showing the rate of evaluation from the students in Test 2

\begin{tabular}{|c|c|c|c|c|c|c|c|c|}
\hline $\begin{array}{c}\text { Criteria of } \\
\text { Evaluation }\end{array}$ & \multicolumn{2}{|c|}{ Rating 4 } & \multicolumn{2}{c|}{ Rating 3 } & \multicolumn{2}{c|}{ Rating 2 } & \multicolumn{2}{c|}{ Rating 1 } \\
\cline { 2 - 8 } & $\begin{array}{c}\text { No. of } \\
\text { Students }\end{array}$ & $\begin{array}{c}\text { Percentage } \\
\%\end{array}$ & $\begin{array}{l}\text { No. of } \\
\text { Students }\end{array}$ & $\begin{array}{c}\text { Percentage } \\
\%\end{array}$ & $\begin{array}{c}\text { No. of } \\
\text { Students }\end{array}$ & $\begin{array}{c}\text { Percentage } \\
\%\end{array}$ & $\begin{array}{c}\text { No. of } \\
\text { Students }\end{array}$ & $\begin{array}{c}\text { Percentage } \\
\%\end{array}$ \\
\hline $\begin{array}{c}\text { Level of } \\
\text { learning } \\
\text { objective }\end{array}$ & 29 & $58 \%$ & 17 & $34 \%$ & 4 & $8 \%$ & - & $0 \%$ \\
\hline $\begin{array}{c}\text { Content } \\
\text { coverage }\end{array}$ & 18 & $36 \%$ & 24 & $48 \%$ & 8 & $16 \%$ & - & $0 \%$ \\
\hline $\begin{array}{c}\text { Practice of } \\
\text { writing } \\
\text { skills }\end{array}$ & 29 & $58 \%$ & 15 & $30 \%$ & 6 & $12 \%$ & - & $0 \%$ \\
\hline $\begin{array}{c}\text { Length of } \\
\text { exam (time } \\
\text { to } \\
\text { complete) }\end{array}$ & 14 & $28 \%$ & 22 & $44 \%$ & 13 & $26 \%$ & 1 & $2 \%$ \\
\hline $\begin{array}{c}\text { Exam } \\
\text { constructio } \\
\mathrm{n}\end{array}$ & 8 & $16 \%$ & 14 & $28 \%$ & 24 & $48 \%$ & 4 & $8 \%$ \\
\hline $\begin{array}{c}\text { Test re- } \\
\text { usability }\end{array}$ & 21 & $42 \%$ & 15 & $30 \%$ & 12 & $24 \%$ & 2 & $4 \%$ \\
\hline $\begin{array}{c}\text { Prevention } \\
\text { of cheating }\end{array}$ & 11 & $22 \%$ & 20 & $40 \%$ & 12 & $24 \%$ & 7 & $14 \%$ \\
\hline
\end{tabular}

A graph showing the rate of evaluation from the students in Test 2

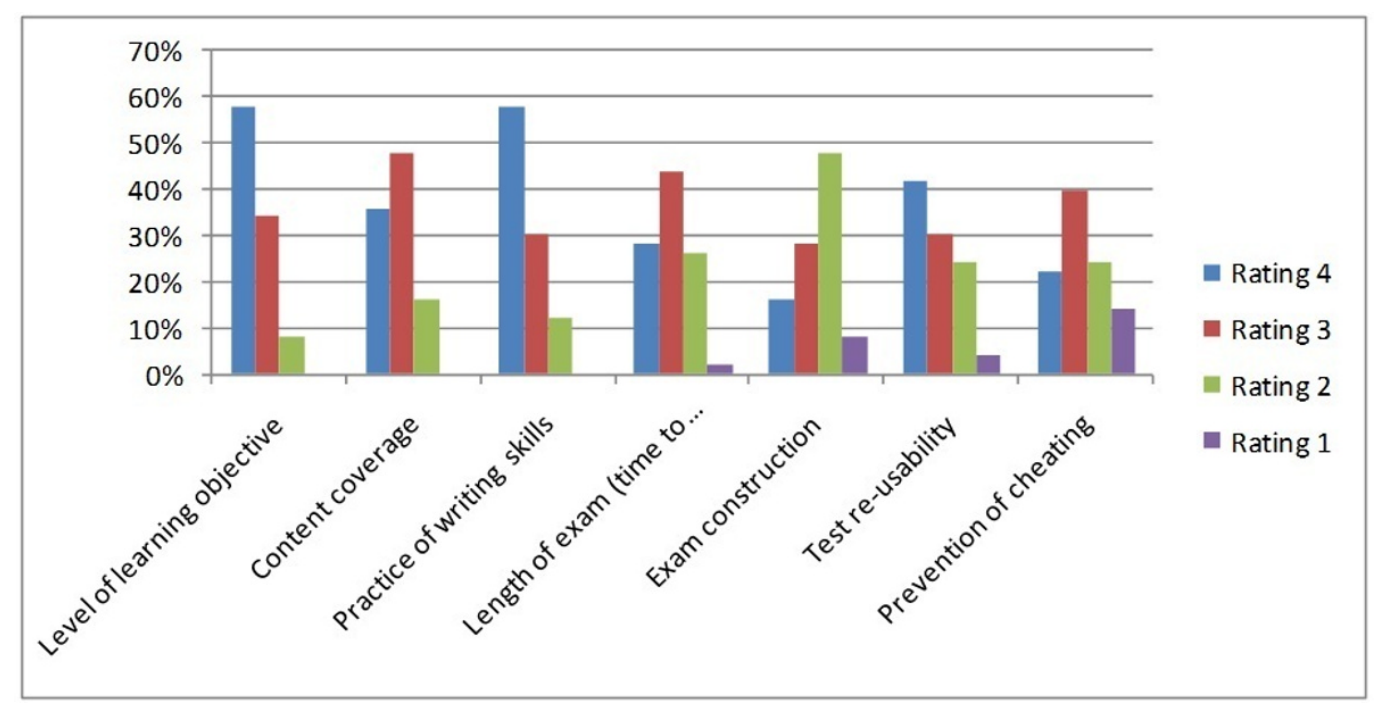

The graph and table in presentation 5 shows the ratings from the students for 
Test 2, 4 being the highest and 1 as the lowest. Level of Learning Objective and Practice of Writing Skills got the highest survey for Rating 4 which is $58 \%$. Exam Construction got the lowest survey for Rating 4 which is $16 \%$.

\section{Presentation 6}

A table comparing the percentage of evaluation from the students of Test 1 and 2

\begin{tabular}{|c|c|c|c|c|c|c|c|c|}
\hline \multirow{3}{*}{$\begin{array}{l}\text { Criteria of } \\
\text { Evaluation }\end{array}$} & \multirow{2}{*}{\multicolumn{2}{|c|}{$\begin{array}{l}\text { Rating } 4 \\
\text { Percentage } \\
\%\end{array}$}} & \multirow{2}{*}{\multicolumn{2}{|c|}{$\begin{array}{l}\text { Rating } 3 \\
\text { Percentage } \\
\%\end{array}$}} & \multirow{2}{*}{\multicolumn{2}{|c|}{$\begin{array}{l}\text { Rating } 2 \\
\text { Percentage } \\
\%\end{array}$}} & \multirow{2}{*}{\multicolumn{2}{|c|}{$\begin{array}{l}\text { Rating 1 } \\
\text { Percentage } \\
\%\end{array}$}} \\
\hline & & & & & & & & \\
\hline & $\begin{array}{l}\text { Test } \\
1\end{array}$ & $\begin{array}{l}\text { Test } \\
2\end{array}$ & $\begin{array}{l}\text { Test } \\
1\end{array}$ & $\begin{array}{l}\text { Test } \\
2\end{array}$ & $\begin{array}{l}\text { Test } \\
1\end{array}$ & $\begin{array}{l}\text { Test } \\
2\end{array}$ & $\begin{array}{l}\text { Test } \\
1\end{array}$ & $\begin{array}{l}\text { Test } \\
2\end{array}$ \\
\hline $\begin{array}{l}\text { Level of learning } \\
\text { objective }\end{array}$ & 18 & 58 & 46 & 34 & 36 & 8 & 0 & 0 \\
\hline Content coverage & 36 & 36 & 50 & 48 & 10 & 16 & 2 & 0 \\
\hline $\begin{array}{l}\text { Practice of writing } \\
\text { skills }\end{array}$ & 28 & 58 & 48 & 30 & 42 & 12 & 2 & 0 \\
\hline $\begin{array}{l}\text { Length of exam } \\
\text { (time to complete) }\end{array}$ & 34 & 28 & 40 & 44 & 16 & 26 & 10 & 2 \\
\hline $\begin{array}{l}\text { Exam } \\
\text { construction }\end{array}$ & 20 & 16 & 36 & 28 & 34 & 48 & 10 & 8 \\
\hline Test re-usability & 22 & 42 & 44 & 30 & 28 & 24 & 6 & 4 \\
\hline $\begin{array}{l}\text { Prevention of } \\
\text { cheating }\end{array}$ & 20 & 22 & 24 & 40 & 12 & 24 & 4 & 14 \\
\hline
\end{tabular}

A graph comparing the difference of evaluation from the students of Test 1 and 2

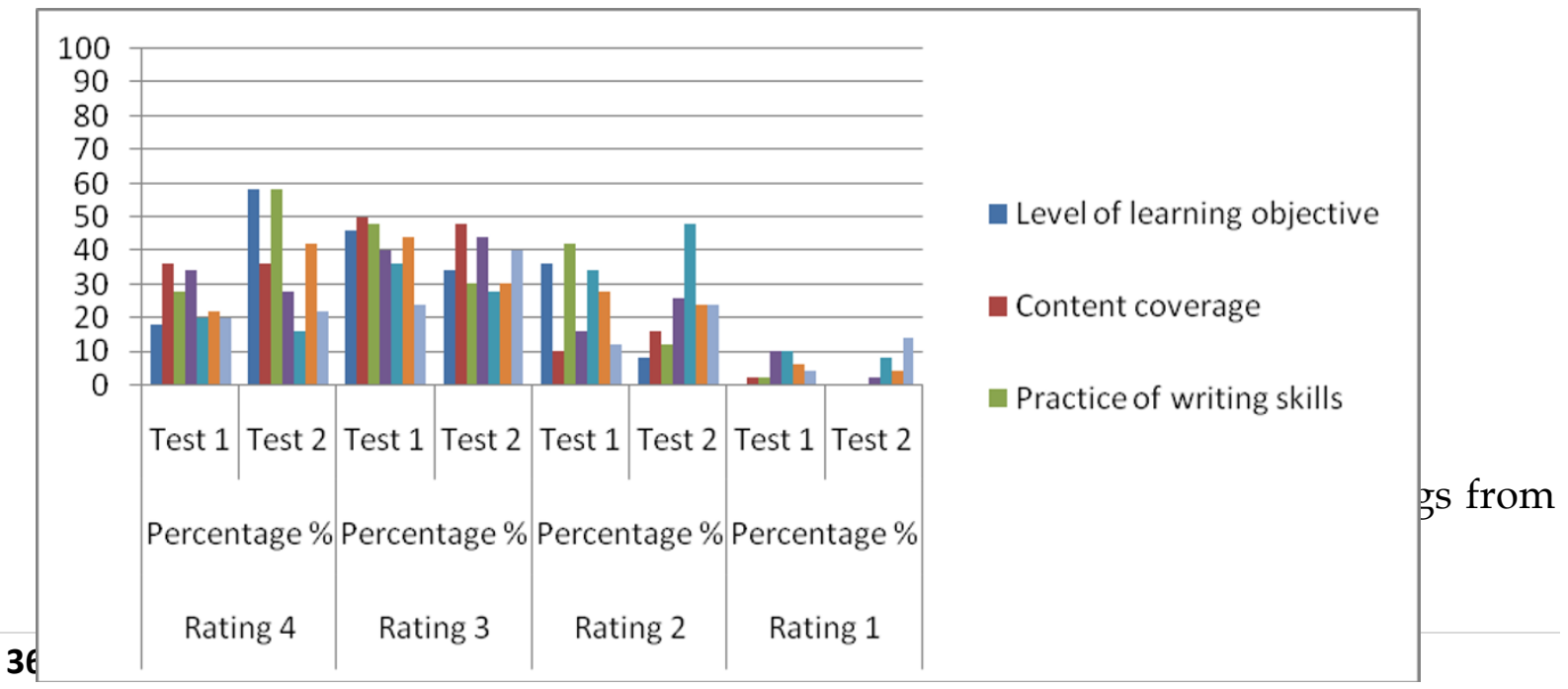


the students for Test 1and 2, 4 being the highest and 1 as the lowest. Test 2 results shows a greater percentage to most of the criteria than Test 1 except for Length of Exam (time to complete) and Exam Construction. Level of learning objective, Content Coverage, and Practice of Writing skills, however, got $0 \%$ from rating 1 of Test 2.

\section{Conclusion and Recommendation}

The following information were gathered, interviewed and made several conclusions from Assumption College IEP Grade 7 students who took the exam under study.

In Test 1 , students found the test moderately difficult to answer. Most of them did not get the correct answer although the test is mostly multiple choice. On the point of view of smart students, Part 1 of the test was too easy for the below average students to copy and to guess the answer since there were only 4 letters to choose from. Part 2 of Test 1 was too difficult for them for there were no sample answers or language structure to follow on the writing test which they were used to do. Most of the respondents agreed that they should have answered the test easier if there were pictures attached to it.

Test 2 received more positive feedback from the respondents. They enjoyed doing the test and found it easy to answer because there were colorful pictures attached to most of the items which gave them clues. Since the test was modified, students had a hard time copying the answer from their friends. To most of them, they felt relaxed and stress - free while doing the examination. In the writing test however, was their major problem, specially to below average students because they 
had difficulty in constructing sentences. Compared to test 1 , they preferred the second test because it is more interesting, not too easy nor too difficult to answer, and the instructions are not too complicated.

Through the information and data gathered in this study, the researcher, therefore, recommends the following:

1. Teachers should construct grammar test that meets the specific objective of a certain topic. The test should not be a punishment to the students but a tool of motivating them to learn the language easier. It should be based on basic knowledge and should used different test type in order for the students to enjoy answering the test.

2. Teachers should consider making revisions on their test specially if most of the students failed the first test. This will help them evaluate and assess student's improvement in the classroom. The researcher believes that if students are exposed to interesting yet challenging grammar test, they will overcome more difficult test when study to a higher level. As they learn and master grammar every step of the way, students will have the benefit of obtaining scholarships and have the possibility to be an exchange student to foreign countries.

3. Measuring and evaluating the proper grammar test may help and develop the models of teaching and will be able to measure students' abilities accurately. Finally, it is a tool in helping students gain knowledge equivalent to the capabilities of other students. 


\section{References}

Charters, W. W. (1920, April). Constructing a language and grammar scale. The Journal of Educational Research, 1 (4), 249-257.

Farrel, T. (2005, September). Conceptions of grammar teaching: A case study of teachers' beliefs and classroom practices. TESL-EJ, 50 Retrieved from http:/ / www.tesl-ej.org/wordpress/issues/volume9/ ej34/ej34a9/

Frost, R. (2011, January). Testing and Assessment. Retrieved from http:/ / www.chaafi.com/index.php?option=com_content\&view=article\&id=8 2:test-assess\&catid=27:links\&Itemid $=28$

You Can Teach Writing: Essential-grammar. (2010, April 21). Retrieved from http:/ / www.you-can-teach-writing.com/essential-grammar.html

\section{Appendix}

\section{Present Simple Test 1}

\section{Objectives:}

1. To be able to use the verb that agrees to the subject in Present simple tense

2. To understand the use of adverbs of frequency in present simple tense

3. To write an interrogative sentence in negative form into present simple tense

4. To communicate on a daily basis in present simple tense

Part I. Choose the best answer.

1. $\mathrm{He}$ to work by bus.
a. go
b. goes
c. went
d. going

2. She with a strange accent. 

a. speaks
b. was speaking
c. had spoken
d. has spoken

3. This room very little sunshine.
a. get
b. gets
c. got
d. will get

4. We ..the puppy on bread and warm milk.
a. feed
b. feeds
c. is fed
d. has feeding

5. People food and water.
a. want
b. wanted
c. wants
d. are wanted

6. The child lessons before goes to bed.
a. study
b. studys
c. studies
d. studied

7. The baby loudly.
a. cry
b. cried
c. crys
d. cries

8. I two ball pens and one highlight marker.
a. buy
b. buys
c. bought
d. am buying

9. Peter his car by himself.
a. fix
b. fixs
c. fixes
d. has fixed

10. She at school 7:30 a.m.
a. arrive b. will arrive
c. has arrived
d. arrives

11. Mary and I them English when we see them once a week.
a. teach
b. teachs
c. teaches
d. taught

12. Saturday usually our busiest day.
a. is
b. are
c. be
d. does

13. I often through the park on my way home from school every Friday. 

a. go
b. goes
c. going
d. went

14. Sometimes I take food with me and sometimes I food when I'm there.
a. buy
b. buys
c. bought
d. has bought

15. The children always to be hungry.
a. seem
b. seems
c. will seem
d. have seem

16. I .usually home by 6 o'clock.
a. am
b. has
C. is
d. are

17. They seldom these days.
a. watch
b. watches
c. watched
d. watching

18. Our parent never jeans.
a. wear
b. wore
c. will wear
d. wears

19. We a shower twice a day.
a. take
b. will take
c. takes
d. is taking

20. His son often football in the evening.
a. play
b. plays
c. played
d. playing

21. have boiled rice for breakfast?
a. Are you
b. Have you
c. Do you
d. Had you

22. the movie?
a. Do you like
b. Are you like
c. Do you
d. Like you

23. What your best friend's name?
a. does
b. has
c. are
d. is

24. she our new English instructor? 

a. Is
b. Are
c. Do
d. Carlos

25. How he the flute?
a. does, plays
b. does, play
c. do, play
d. do, play

26. Their brother put his handbag here.
a. doesn't always put
b. don't always put
c. don't always puts
d. doesn't always puts

27. Kath early in the morning.
a. doesn't work
b. doesn't works
c. isn't work
d. hasn't worked

28. Our family speak softly to each other.
a. does
b. doesn't
c. don't
d. isn't

29. I don't watching boxing.
a. like
b. likes
c. liked
d. have liked

30. Dan a new $C D$.
a. don't buy b. doesn't buy
c. don't buys
d. doesn't buys

Part II. Arrange the words below to make sentences into present simple tense.

31. My mom / every morning

32. I / like

33. Tony / dish 
34. listen to the radio

35. news on TV

36. visit

37. get up

38. do homework

39. get up

40. wear old clothes

\begin{tabular}{|c|c|}
\hline No. & Points \\
\hline Subj. - V. Agreement & \\
\hline $11-20$ Adverb of frequency Usage & \\
\hline 21 -30 Negative / Question Form & \\
\hline $31-40$ Communication & \\
\hline
\end{tabular}

\section{Present Simple Test 2}

Objectives:

5. To be able to use the verb that agrees to the subject in Present simple tense

6. To understand the use of adverbs of frequency in present simple tense

7. To write an interrogative sentence in negative form into present simple tense 
8. To communicate on a daily basis in present simple tense

Part I. Write the verbs agree the subjects on the top

$$
\begin{aligned}
& +=\text { positive } \\
& -\quad=\text { negative }(\text { not }) \\
& ?=\text { question }
\end{aligned}
$$

\begin{tabular}{|c|c|c|c|c|}
\hline & I & You & He or She & $\begin{array}{l}\text { They } \\
\text { Thent }\end{array}$ \\
\hline Smi & $\begin{array}{l}+\ldots \ldots \ldots \ldots \\
\ldots \ldots \ldots \ldots \ldots \\
\ldots \ldots \ldots \ldots \ldots \\
\ldots ?\end{array}$ & $\begin{array}{l}+\ldots \ldots \ldots \ldots \\
\ldots \ldots \ldots \ldots \ldots \\
\ldots \ldots \ldots \ldots \ldots \ldots \\
\ldots \ldots \ldots ?\end{array}$ & $\begin{array}{l}+\ldots \ldots \ldots \ldots \ldots \\
\ldots \ldots \\
\ldots \ldots \ldots \ldots \ldots \ldots \\
\ldots \ldots ?\end{array}$ & $\begin{array}{l}+\ldots \ldots \ldots \ldots \ldots \ldots \\
\ldots \ldots \ldots \ldots \ldots \ldots \ldots \ldots \\
\ldots \ldots \ldots \ldots \ldots \ldots \ldots \ldots \\
\ldots \ldots \ldots \ldots \ldots \ldots\end{array}$ \\
\hline 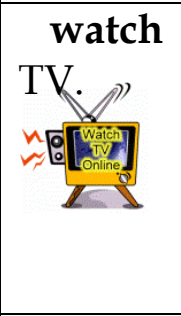 & $\begin{array}{l}+\ldots \ldots \ldots \ldots \ldots \\
\ldots \ldots \ldots \ldots \cdots ?\end{array}$ & $\begin{array}{l}+\ldots \ldots \ldots \ldots \ldots \\
\ldots \ldots \ldots \ldots \ldots \ldots \\
\ldots \ldots \ldots \ldots \ldots \\
\ldots \ldots \ldots \ldots \ldots \ldots \\
?\end{array}$ & $\begin{array}{l}+\ldots \ldots \ldots \ldots \ldots \ldots \ldots \ldots \\
\ldots \ldots \ldots \\
\ldots \ldots \ldots \ldots \ldots \ldots \ldots \ldots \ldots \\
\ldots \ldots \ldots\end{array}$ & $\begin{array}{l}+\ldots \ldots \ldots \ldots \ldots \ldots \ldots \\
\ldots \ldots \ldots \ldots \ldots \ldots \ldots \ldots \ldots \\
\ldots \ldots \ldots \ldots \ldots \ldots \ldots \ldots \ldots \ldots \ldots\end{array}$ \\
\hline go out & $\begin{array}{l}+\ldots \ldots \ldots \ldots \ldots \\
\ldots .- \\
\ldots \ldots \ldots \ldots \ldots \ldots \\
\ldots \ldots\end{array}$ & $\begin{array}{l}+\ldots \ldots \ldots \ldots, \\
\ldots \ldots \ldots- \\
\ldots \ldots \ldots \ldots \ldots \cdots \\
\ldots \ldots \ldots\end{array}$ & $\begin{array}{l}+\ldots \ldots \ldots \ldots \ldots \ldots \ldots \\
\ldots \ldots \ldots \\
- \\
\ldots \ldots \ldots \ldots \ldots \ldots \ldots \ldots \ldots \\
\ldots \ldots\end{array}$ & $\begin{array}{l}+\ldots \ldots \ldots \\
\ldots \ldots \ldots \\
- \\
\ldots \ldots \ldots \\
\ldots \ldots\end{array}$ \\
\hline cry & $\begin{array}{l}+\ldots \ldots \ldots \ldots \\
\ldots . \\
-\ldots \ldots \ldots \ldots\end{array}$ & $\begin{array}{l}+\ldots \ldots \ldots \ldots \ldots \\
\ldots \ldots \\
-\ldots \ldots \ldots \ldots \ldots\end{array}$ & $\begin{array}{l}+\ldots \ldots \ldots \\
\ldots \\
-\ldots \ldots \ldots\end{array}$ & $\begin{array}{l}+\ldots \\
\ldots \ldots \\
-\ldots \ldots\end{array}$ \\
\hline sing & $\begin{array}{l}+\ldots \ldots \ldots \ldots . \\
\cdot \\
- \\
\ldots \ldots \ldots \ldots \ldots \\
.\end{array}$ & $\begin{array}{l}+\ldots \ldots \ldots \ldots \\
\ldots \ldots \ldots \\
\ldots \ldots \ldots \ldots \ldots \\
\ldots \ldots ?\end{array}$ & $\begin{array}{l}+\ldots \ldots \ldots \ldots \ldots \ldots \ldots \ldots \\
\ldots \ldots \ldots \\
- \\
\ldots \ldots \ldots \ldots \ldots \ldots \ldots \ldots \ldots \ldots \\
\ldots\end{array}$ & $\begin{array}{l}+\ldots \ldots \ldots \ldots \\
\ldots \ldots \ldots \\
\ldots \ldots \ldots \ldots \\
\ldots \ldots \ldots\end{array}$ \\
\hline
\end{tabular}


Negative / Question = 20 Points Average 10

Part II. Underline the words to show you to make the verbs into Present Simple

Tense.

1. She always arrives at school at 7:30 a.m.

\begin{tabular}{|c|c|c|c|c|c|c|}
\hline $\begin{array}{c}\text { Monda } \\
\text { y }\end{array}$ & Tuesday & $\begin{array}{c}\text { Wednes } \\
\text { day }\end{array}$ & Thursday & Friday & Saturday & Sunday \\
\hline$\checkmark$ & $\checkmark$ & $\checkmark$ & $\checkmark$ & $\checkmark$ & $\checkmark$ & $\checkmark$ \\
\hline
\end{tabular}

2. I sometimes write to him.

\begin{tabular}{|c|c|c|c|c|l|l|}
\hline $\begin{array}{c}\text { Monda } \\
\mathrm{y}\end{array}$ & Tuesday & $\begin{array}{c}\text { Wednes } \\
\text { day }\end{array}$ & Thursday & Friday & Saturday & Sunday \\
\hline$\checkmark$ & & & $\checkmark$ & & $\checkmark$ & $\checkmark$ \\
\hline
\end{tabular}

3. He usually gets home about 6 o'clock.

\begin{tabular}{|c|c|c|c|c|c|c|}
\hline $\begin{array}{l}\text { Monda } \\
\mathrm{y}\end{array}$ & Tuesday & $\begin{array}{l}\text { Wednes } \\
\text { day }\end{array}$ & Thursday & Friday & Saturday & Sunday \\
\hline$\checkmark$ & & $\checkmark$ & $\checkmark$ & $\checkmark$ & $\checkmark$ & $\checkmark$ \\
\hline
\end{tabular}

4. You often go through the park on your way home from school.

\begin{tabular}{|c|c|c|c|c|c|c|}
\hline $\begin{array}{l}\text { Monda } \\
\mathrm{y}\end{array}$ & Tuesday & $\begin{array}{l}\text { Wednes } \\
\text { day }\end{array}$ & Thursday & Friday & Saturday & Sunday \\
\hline$\checkmark$ & $\checkmark$ & $\checkmark$ & $\checkmark$ & $\checkmark$ & & $\checkmark$ \\
\hline
\end{tabular}

5. They visit their grandparents in London every year.

\begin{tabular}{|c|c|c|c|c|c|c|}
\hline 2006 & 2007 & 2008 & 2009 & 2010 & Saturday & \\
\hline$\checkmark$ & $\checkmark$ & $\checkmark$ & $\checkmark$ & $\checkmark$ & $\checkmark$ & $\checkmark$ \\
\hline
\end{tabular}

6. I rarely see my parents now.

\begin{tabular}{|c|c|c|c|c|c|c|}
\hline $\begin{array}{l}\text { Monda } \\
\mathrm{y}\end{array}$ & Tuesday & $\begin{array}{l}\text { Wednes } \\
\text { day }\end{array}$ & Thursday & Friday & Saturday & Sunday \\
\hline$\checkmark$ & $\checkmark$ & $\checkmark$ & & $\checkmark$ & & $\checkmark$ \\
\hline
\end{tabular}

7. I have never been to America.

was born

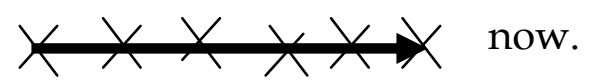

8. They seldom drink beer these days.

\begin{tabular}{|c|c|c|c|c|c|c|}
\hline $\begin{array}{l}\text { Monda } \\
\mathrm{y}\end{array}$ & Tuesday & $\begin{array}{l}\text { Wednes } \\
\text { day }\end{array}$ & Thursday & Friday & Saturday & Sunday \\
\hline$\checkmark$ & $\checkmark$ & $\checkmark$ & & $\checkmark$ & & $\checkmark$ \\
\hline
\end{tabular}

9. He sees her once a week. 


\begin{tabular}{|l|c|l|l|l|l|l|}
\hline $\begin{array}{l}\text { Monda } \\
\text { y }\end{array}$ & Tuesday & $\begin{array}{l}\text { Wednes } \\
\text { day }\end{array}$ & Thursday & Friday & Saturday & Sunday \\
\hline & $\checkmark$ & & & & & \\
\hline
\end{tabular}

10. He visits his parents twice a month.

Adverbs of frequency 10 Points $=$

Part III. Write five sentences from this timetable.

\begin{tabular}{|c|c|c|c|c|}
\hline Subject & Adverb & Verb & $\begin{array}{l}\text { Predicate } \\
\end{array}$ & Adv. \\
\hline $\begin{array}{l}\text { I / You / } \\
\text { We / They } \\
\text { / He / } \\
\text { She } \\
\text { /David/ } \\
\text { Sara...etc. }\end{array}$ & $\begin{array}{l}\text { always } \\
\text { sometimes } \\
\text { usually } \\
\text { often }\end{array}$ & $\begin{array}{l}\text { write } \\
\text { drive } \\
\text { drink }\end{array}$ & $\begin{array}{l}\text { the car } \\
\text { lessons } \\
\text { coffee } \\
\text { clothes } \\
\text { the heavy bag } \\
\text { dishes }\end{array}$ & $\begin{array}{l}\text { every } \\
\text { (............. } \\
\text { (day/week } \\
\text { /month/ye } \\
\text { ar/Monda } \\
\text { y/ ....... } \\
\text { etc.) }\end{array}$ \\
\hline
\end{tabular}

1.

2.

3.

4.

5.

Part IV. Match sentences with match the pictures.

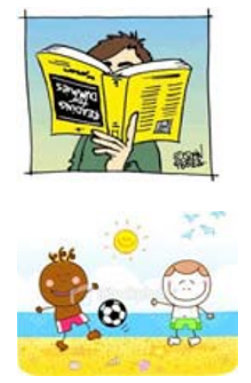

a.

() Mom often eats cake and read books together.

b.

po Children should drink milk daily. 


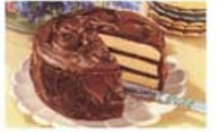

c.

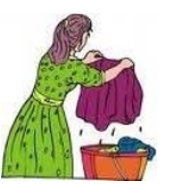

d.

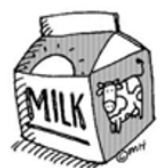

e.

Communication 10 Points $=$
We always read books before going to bed.

Susan is very tired because she washes clothes every day.

My aunt takes her children to the beach every year.

Test 1- and Test 2 in Present Simple Tense Questionnaires

$$
\begin{array}{lll}
4 & = & \text { excellent } \\
3 & = & \text { very satisfactory } \\
2 & = & \text { satisfactory } \\
1 & = & \text { needs improvement }
\end{array}
$$

Direction: Mark $\checkmark$ to the appropriate ratings to each criterion of evaluation.

\begin{tabular}{|l|l|l|l|l|l|}
\hline \multirow{2}{*}{ No. } & Criteria of Evaluation & \multicolumn{4}{|l|}{ Ratings } \\
\cline { 3 - 6 } & 4 & 3 & 2 & 1 \\
\hline 1 & Level of learning objective & & & & \\
\hline 2 & Content coverage & & & & \\
\hline 3 & Practice of writing skills & & & & \\
\hline 4 & Length of exam (time to complete) & & & & \\
\hline 5 & Exam construction & & & & \\
\hline
\end{tabular}




\begin{tabular}{|l|l|l|l|l|l|}
\hline 6 & Test reusability & & & & \\
\hline 7 & Prevention of cheating & & & & \\
\hline
\end{tabular}

Remark/Suggestion:

Here are the explanations per criteria:

1. Level of learning objective: to check whether the test is appropriate to the level of understanding of the students (The difficulty of test )

2. Content coverage: to measure the student's knowledge on a specific topic (The appropriateness of test to grade 7 students of ACT to measure authentic assessment of students with basic learning from other students.)

3. Practice writing skills: to identify students' ability to construct simple and grammatically correct sentences.

(I want the form as test 1 to evaluate the main grammar or testing on various topics.)

4. Length of exam (time to complete): to check if the students have enough time in finishing the test.

(Satisfaction of test)

5. Exam construction: "None of the information should include clues that point to the correct answer or be written in a way that confuses student reading and 
interpretation of the item." To evaluate whether the students think the correct answer or only guess the answer.

(Satisfaction of test)

6. Test reusability: “More items are more difficult for students to remember and transmit to those who will take the exam later (if the printed exam does not get into circulation)." To check whether it can also be used to another set of students.

(Attitudes or inspire the need to do test)

7. Prevention of cheating: to check whether the answers are easy to copy or not (Attitudes or inspire the need to do test.) 